\title{
Gini Katsayısı ile Türkiye'deki Üniversitelerin Araştırma Çıktıları Arasındaki Farkın Değerlendirilmesi ${ }^{1}$
}

\section{Evaluating the Research Outputs of Turkish Universities Using Gini Coefficient}

\section{Prof. Dr. Handan YOLSAL2 - Doç. Dr. Özlem YORULMAZ3}

Başvuru Tarihi: 04.03.2019

Kabul Tarihi: 13.09.2019

Öz

Toplumsal ve ekonomik kalkınmaya önemli katkı sağlayan üniversiteler, eğitim kaliteleri, araştırma çıktıları, uluslararası görünümleri ve endüstri bağlantıları gibi ölçütler baz alınarak her yıl sıralanırlar. Dünya genelindeki üniversitelerin stralanmasında dikkate alınan farklı sistemler vardır. Bu çalışma, söz konusu sıralama sistemlerinden URAP-TR dikkate alınarak, 2010-2018 yılları arasında Türkiye'deki üniversiteler için Gini katsayılarının hesaplanmasına ve üniversiteler arasındaki farkın yıllar bazında değerlendirilmesine dayanır. Çalışmada Gini katsayıları hesaplanırken, hem tüm üniversiteler, hem de bünyesinde tıp fakültesi barındıran ve barındırmayan üniversiteler kendi içlerinde ayrı ayrı değerlendirilmiştir. Elde edilen Gini katsayısı ve Lorenz eğrisi bulgularına göre, en yüksek eşitsizlik 2010/2011 döneminde doktora ögrencisi göstergesinde mevcuttur. Makale sayısı ve doküman sayısı göstergeleri açısından değerlendirildiğinde ise tüm üniversiteler arasindaki farkların zamanla kapandiğl, hatta bünyesinde tıp fakültesi barındıran ve barındırmayan üniversitelerin kendi içlerinde neredeyse eşit olduğu sonucuna ulaşılmıştır. Bununla beraber bünyesinde tıp fakültesi barındıran ve barındırmayan üniversitelerin araştırma çıktıları arasında istatistiksel açıdan anlamlı fark olduğu sonucuna varılmıştır.

Anahtar Kelimeler: Gini Katsayısı, Lorenz Ĕgrisi, Üniversiteleri Sıralaması Sistemleri, URAP

\footnotetext{
1 Çalıșma aynı isimle 19. Uluslararası Ekonometri, Yöneylem Araștırması ve İstatistik Sempozyumu 2018'de sözlü olarak sunulmuș ve özeti sempozyum kitapçığında yayımlanmıştır. Çalışma bildiri olarak sunulduktan sonra 2018 yılı verileri de eklenerek yeniden gözden geçirilmiştir.

2 İstanbul Üniversitesi İktisat Fakültesi, yolsalh@istanbul.edu.tr, ORCID: 0000-0002-1575-2251

${ }^{3}$ İstanbul Üniversitesi İktisat Fakültesi, yorulmaz@istanbul.edu.tr, ORCID: 0000-0003-1029-5749
} 


\section{Abstract}

Universities that provide significant contributions to economic and social progress of societies have been ranked according to various criteria such as education qualities, research outputs, international aspects and industrial connections each year. There are different systems to rank worldwide universities. This study is based on the calculation of Gini coefficients of Turkish universities and the evaluation of the differences between the universities for each of the years from 2010 to 2018 considering one of the aforementioned systems namely, URAP-TR. While calculating the Gini coefficients, universities with medical faculties, universities without medical faculties and all universities are evaluated separately. According to the findings of Gini coefficients and Lorenz curves, the highest inequality belongs to the criteria of the number of Ph D students for the term of 2010/2011. As for the number of articles and scientific publications criteria, the differences between universities are decreased over the years. Moreover, the gaps in universities with medical faculties and without medical faculties are almost zero. Nevertheless, the differences of research outputs between the universities with and without medical faculties are statistically significant.

Keywords: Gini Coefficient, Lorenz Curve, University Rankings System, URAP

\section{Giriş}

Üniversite kavramı birliği, birleştiriciliği, bütün bilgi dallarında evrensel nitelikte bilgi üretmeyi ve bunları yaymayı ifade etmektedir (Bolay, 2011). Üniversiteler bilgiyi yaratma ve yayma işlevleri aracılığı ile toplumu aydınlatma ve böylece toplumun sosyo- ekonomik ve kültürel gelişmişlik düzeyini artırma görevlerini yürütürler. Bu işlevler üniversitelerin en önemli kamusal sorumluluklarındandır. Böylece üniversitelerin topluma öncülük etmesi, kaliteyi artırması ve kalkınmaya katkı yapması beklenmektedir. Bu bağlamda üniversitelerin başlıca üç görevi vardır. Bu görevler kitlesel eğitim hizmeti vermek, araştırma yapmak ve dolayısıyla topluma hizmet etmektir. Bu görevler çoğu kere iç içe girmiştir. Türkiye'de üniversiteler üstlendikleri görevlere göre örgütlenmemiş olup, ağırlıklı olarak eğitim ve öğretim görevini yerine getirmektedir (Erdem, 2013). Bununla beraber, Yükseköğretim Kurulu (YÖK) 2017 yılında yeni bir uygulama başlatmış ve araştırma üniversitesi kavramını gündeme getirmiştir. $\mathrm{Bu}$ düzenlemeye bağlı olarak araştırma üniversitesi olma isteğini beyan eden 58 devlet üniversitesinden 10 üniversiteyi YÖK araştırma üniversitesi olarak açıklamıştır. Araştırma üniversitesi, ağırlıklı olarak araştırmayapan, bu araştırmaları disiplinler arası ve farklı kurumlarla ortak olarak geliştirebilen, araştırma vasfı gelişmiş doktora öğrencisi yetiştiren, proje üreten, eğitim-öğretim faaliyetlerine de aynı derecede önem veren yükseköğretim kurumları olarak tanımlanmaktadır. Araştırma üniversiteleri, aynı zamanda öğrencilerine de araştırma ruhunu aşılamış, yürüttüğü araştırmalarla fon sağlayıcılardan katkı alarak, ek bütçe yaratabilen, saygın dergilerde yayın yapan öğretim üyelerinin bulunduğu kurumlardır. Araştırma üniversitelerinin bu özellikleri ile uluslararası sıralamalarda daha yüksek sıralara 
yerleşmesi ve kurum olarak tanınmışlıklarını artırması hedeflenmektedir (YÖK, 2018). 2017 yllında araştırma üniversitesi olarak kabul edilen üniversiteler Ankara Üniversitesi, Boğaziçi Üniversitesi, Erciyes Üniversitesi, Gazi Üniversitesi, Gebze Teknik Üniversitesi, Hacettepe Üniversitesi, İstanbul Üniversitesi, İstanbul Teknik Üniversitesi, İzmir Yüksek Teknoloji Enstitüsü, Orta Doğu Teknik Üniversitesidir. Bu üniversitelerin URAP (University Ranking by Academic Performance) tarafından 2018-2019 yllında yapılan dünya üniversiteleri sıralamada ilk 1500'e girdiği görülmektedir (URAP, 2019). Bu üniversiteler aynı zamanda URAP'ın Türk üniversiteleri arasında yaptı̆̆ı sıralamada en yüksek sıralara yerleşmektedir.

Türkiye'deki üniversitelerin performanslarının ölçümünde kullanılan güvenilir iki sıralamadan söz edilebilir (Erkut, 2015). Bunlardan ilki üniversiteleri 9 farkl akademik performans göstergesi ile değerlendiren Orta Doğu Teknik Üniversitesi'nde 2009 yllında Enformatik Enstitüsü bünyesinde kurulan ve kâr amacı gütmeyen Akademik Performans Araştırma Laboratuvarı tarafından geliştirilen URAP'tır. URAP'ın amacı akademik performansı ölçmek için bilimsel yöntemler geliştirmek ve üniversitelerin kendilerini klyaslanabileceği raporlar hazırlayarak, sonuçları kamuoyuna duyurmaktır (URAP, 2017). Türkiye'deki üniversitelerin performanslarını ölçmek için geliştirilen diğer sıralama ise, TÜBİTAK tarafından hazırlanan ve üniversiteleri 23 adet girişimcilik ve yenilikçilik ölçütüne göre değerlendiren "girişimci ve yenilikçi üniversite endeksidir”. Bu sıralamada ülkenin en girişimci ve yenilikçi 50 üniversitesi sıralanmaktadır (TÜBİTAK, 2017).

Bu çalı̧mada 2010-2018 yılları arasında ulusal düzeydeki URAP sıralamalarına dayanarak Türkiye'deki 121 üniversitenin araştırma çıktıları arasındaki fark Gini katsayısı ile ölçülmüştür. Çalışmanın ikinci bölümünde üniversite sıralama sistemlerinin dayandığı ilkeler hakkında bilgi verilerek, URAP tarafından sıralamada kullanılan göstergeler açıklanmıştır. Üçüncü bölümde ise, dünyada üniversitelerin sıralamalarını Gini katsayısı ile ölçen çalışmalardan örneklerin verildiği yazın taraması yer almaktadır. Dördüncü bölümde Gini katsayısı açıklanmış ve beşinci bölümde de Türk üniversiteleri ile ilgili bilgiler verilerek veri tasarımı yapılmıştır. Bu bölümde ayrıca Türkiye'deki üniversiteler arasındaki eşitsizliği ölçmek üzere ilk olarak 121 üniversite için Gini katsayısı hesaplanmıştır. Ardından bünyesinde tıp fakültesi olan ve tıp fakültesi olmayan üniversitelerin eşitsizliği kendi içinde yeniden değerlendirilmiştir. Sonuç bölümünde ise bulgular tartışılmıştır.

\section{Üniversite Sıralama Sistemlerinin Dayandığı ilkeler ve URAP}

Ekonomik ve toplumsal gelişime katkıda bulunarak toplumun refah düzeyini artırmak üzere var olan üniversiteler; eğitim kaliteleri, araştırma çıktıları, uluslararası görünümleri ve endüstri bağlantıları gibi çeşitli ölçütler dikkate alınarak çeşitli kuruluşlar tarafından her yıl sıralamaya tabi tutulurlar. (Usher ve Savino, 2007). Üniversitelerin siralanması 1983 yllinda US NEWS and WORLD tarafından Amerika Birleşik Devletleri (ABD)'ndeki en iyi kolejlerinin sıralanması ile başlamıştır. Daha sonra pek çok ülkede farklı kuruluşlar bu tip sıralamaları yapmaya başlamıştır. Son yıllarda yüksek eğitim kurumları yalnızca özel veya medya bazlı kurumlar tarafından değil, profesyonel birlikler, üniversiteler ve hükümetler tarafından da sıralamaya tâbi 
tutulmaktadır (Lukman, Krajnc ve Glavic, 2010). Üniversitelerin sıralamasını yapan kuruluşlar genellikle kâr amacı güden çeşitli kuruluşlardır. Üniversiteleri sıralamaktaki amaç;

- Yüksek eğitim programlarını yarışmaya yöneltmek,

- Uluslararası yüksek eğitim pazarını değerlendirmek,

- Ulusal düzeyde üniversitelerin tanıtımına yön vermek,

- Üniversitelere fon sağlayan kurumlar ve profesyoneller ile öğrenciler için olumlu rekabeti yükseltmektir (Lukman et al. 2010).

Bu sıralamalar yüksek eğitim kurumlarının bilimsel kaliteleri ve diğer özellikleri hakkında bilgi sağlar. Üniversitelerin bu sıralamalardaki yerleri, üniversitelerin sahip oldukları insan gücü ve alt yapısı arasındaki farklılıkları açığa çıkararak, yüksek sıralara yerleşen üniversitelerin iyi öğrencileri bünyelerine çekmelerini, devlet ve endüstriden mali destek elde etmelerini ve saygınlık kazanmalarını sağlar. Üniversiteleri sıralamanın her yıl yüksek sıralarda yer almayı hedefleyen üniversitelerin birbirleri ile rekabete girişmesine yol açarak, akademik verimliliğin artmasını sağladığ 1 da düşünülmektedir. Ancak bu durumun istenmeyen bir sonucu olarak, rekabet edemeyen kurumların kapanmaya zorlandığı ve oligopoller yaratıldığı da görülmektedir (Weingart, 2005). Bu sıralamalar ulusal veya uluslararası düzeyde yapıldığı gibi, kurumlar yalnızca tıp fakülteleri, yalnızca hukuk fakülteleri gibi alt kurumlar arasında da sıralanabilir (Usher ve Savino, 2007). Üniversiteleri sıralayan kuruluşların seçtikleri göstergeler, bu göstergelerin sayısı ve bu göstergelere verdikleri ağırlıklar farklı olduğundan, üniversitelere verdikleri puanlar da son derece farklıdır. Bazı sıralamalarda yükseköğretim kurumlarının tanınmışlı̆̆ı, bazılarında öğretim üyesi kalitesi ön plana çıksa da, üniversiteleri sıralayan çoğu kuruluş genellikle üretilen makale sayısı ve atıf sayısı gibi bibliyometrik ${ }^{4}$ göstergeleri kullanmaktadır.

Üniversitelerin araştırma performanslarının bibliyometrik yöntemlerle sıralanmasının uygun olmadığını düşünenler de vardır. Bibliyometrik ölçümler nicel ve dolayısıyla daha nesnel (objektif) olmasına rağmen, teorik alt yapılarının olmaması, deneysel olmaları ve kesin olmayan veriye dayanmaları nedeniyle eleştirilmektedir (Weingart, 2003). Hatta bibliyometrik yöntemlerle araştırma kurumlarının sıralamalarının, araştırma çıktılarının geniş kuramsal çerçevede değerlendirilmesi için uygun bir araç olmadığı, burada asıl ciddi sorunun bibliyometrik ölçümlerin giderek, bilim insanlarını değerlendirir hale gelmesi olduğu; üniversiteleri, üniversiteden olmayan kurumların sıralamaya kalkışması olduğu düşünülmektedir. Bu noktada sorunu sıralama değil de, sıralamada kullanılan göstergelerin yetersizliğinde görenler de vardır. Ancak çoğunlukla üniversitelerde rektörler, dekanlar ve bölüm başkanları, yöneticiler, fon sağlayıcılar ve özellikle politika yapıcılar "çabuk ve kirli” bir bibliyometrik analizi cazip bularak kullanmaktadır. Bu tip sıralamalar üniversitelerin bilimsel verimliliklerinin değerlendirilmesini bir futbol ligine döndürmektedir (van Raan, 2005).

${ }^{4}$ Bibliyometri, belirli bir alanda belirli bir dönemde ve belirli bir bölgede kişiler ya da kurumlar tarafından üretilmiş yayınların ve bu yayınlar arasındaki ilişkilerin sayısal olarak analizidir (http://cabim.ulakbim.gov.tr/bibliyometrik-analiz/bibliyometrik-analiz-sikca-sorulan-sorular/ 'dan alınmıştır. Erişim:20.09.2018). 
Üniversitelerin sıralanması ve sinıflanması üzerine yapılan çalı̧malar 1900'lü yıllara dayanır. Galton 1875 yılında yaptığı çalışma ile bilimdeki başarının kaynağını araştırmış ve başarının İngiliz Kraliyet zümresinin etkisinden mi, bilim insanlarının ve üniversitelerin içsel bir motivasyonundan mı kaynaklandığını değerlendirmiştir. Maclean (1900) ve Ellis (1904) çalışmalarında üniversiteleri başarılı mezunlara dayalı olarak sıralamışlardır. Cattell (1906) Amerikan üniversitelerini en başarılı 1000 bilim insanını dikkate alarak sıralamıştır. Üniversitelerin araştırma çıtıllarının ölçümü 1970'lerden itibaren geliştiği halde, bu çıktılara göre sıralama uygulanmamıştır. Ancak üniversitelerin bütçe tahsisinde daha maliyetli olan blok hibe sisteminin yerine fonların rekabete dayalı tahsisi ile bölümlerin ve bireysel araştırmacıların değerlendirilmesine geçilmesi, üniversitelerin sıralanmasını önemli bir araç haline getirmiştir. Günümüzde araştırma çıktısı göstergeleri yalnızca üniversiteleri değil, kamu fonlarına bağlı olan diğer araştırma kurumlarını klinikleri olduğu kadar araştırma sürecini doğrudan etkileyen bütçe kararlarının temeli haline gelmiştir (Weingart, 2003). Buna rağmen araştırma kalitesini ölçen göstergeler henüz tam olarak kabul edilmemiştir. Örneğin $\mathrm{ABD}$ hükümeti bütçe kararlarının gerçekleşmeleri için performans göstergelerine dayandığı halde, araştırmaların bibliyometrik ölçümünü kullanmamaktadır (Weingart, 2003). Avrupa Birliğinde ise, bibliyometrik göstergelerin kurumsallaşma dereceleri ülkeden ülkeye oldukça farklıdır. Bu konuda en uçörnek Finlandiya'dır. Finlandiya üniversite hastanelerine ayrılan hükümet fonları için etki faktörü (impact factor) yüksek dergilerde yayın yapılması koşulunu kanun ile onaylayan tek ülkedir (Adam, 2002). Günümüzde bütün hükümetler için nicel ölçümler cazibesini artırmaktadır. Bu fikir değişimi yalnızca politika yapıcılar ve yöneticilerle sınırlı kalmayıp, aynı zamanda dekanları, bölüm başkanlarını, rektörleri ve araştırma konseylerindeki, finans kurumlarındaki üniversite yetkililerini, hatta araştırmaların herhangi bir araç ile bir dış değerlendirmeye tâbi tutulmasına kuvvetle karşı çıan bilimsel komisyonların temsilcilerini de etkilemiştir. Böylece araştırma değerlendirme ve özellikle bibliyometrik analiz hızla büyüyen bir pazar oluşturmuştur. Birçok ülke araştırma faaliyetleri ile ilgili verileri işlemek ve toplamak amacıyla kendi kurumlarını kurmuştur. Diğer bazı ülkeler ise üniversite bazında veya ticari kurumlar veya araştırmaların rutin değerlendirmesini yapan bibliyometrik analizlerde uzmanlaşmış bağımsız araştırma gruplarını kullanmaktadır (Weingart, 2003). Günümüzde Institute of Scientific Information (ISI) ${ }^{5}$ bilimsel literatürün çok disiplinli veri bankasını üretmek açısından tekel durumundadır. Kurum, dergilerin etki faktörlerini ve atıf sayılarını derleme ve ortak atıf haritalarını çıkarma gibi karmaşık hesaplamaları yapmaktadır.

Bireysel ve kurumsal değerlendirmede bibliyometrik göstergelerin geçerlilik ve güvenilirliğine gelince; bilimin ölçülmesi sorunu ile karşı karşıya kalınmaktadır. Üniversitelerin sıralamasını yapan kuruluşlar, araştırma performansının ölçümü ve özellikle seçilen göstergelerin standardizasyonu, disiplinler arası ilişkiler, işbirlikleri ve ortak çalışmalar ile bilgi kullanıcıları hakkında kafa yormuştur. Buna göre bilimin ölçülmesi konusunda karşılaşılan sorunlar şöyledir (van Raan 2004):

\footnotetext{
5 Eugene Garfield tarafından 1956'dan beri başkanlığını yaptığı DocuMation Inc.'in adını değiştirerek 1960'da kurduğu ISI (Institute for Scientific Information), 1992'de Thampson Company tarafından 210 milyon USD’a satın alınmıştır (Beira, 2010).
} 
- Kullanilan dilden kaynaklanan sorunlar,

- Zamanlamadan kaynaklanan sorunlar,

- Farklı araştırma sistemlerinin karşılaştırılabilirliğinden kaynaklanan sorunlar,

- Kullanılan istatistiksel yöntemlerden kaynaklanan sorunlar ile

- Göstergelerin teorideki değişmezliği

sorunlarıdır. Van Raan (2004) bilimin ölçülebilirliğini sorguladığı çalışmasında, bu amaçla geliştirilen nicel göstergelerin "ölçülmesinin bilmek” anlamına geldiğini düşünenleri büyülerken, bazılarını da ürküttüğünü belirtmiştir. Van Raan (2004, s.44) çalışmasının sonucunda "bilim ölçülebilir mi?" sorusuna alçakgönüllü de olsa, "evet” cevabı vermektedir. ABD’de yapılan çalışmalar üniversite adaylarının tercih yaparken, üniversitelerin genel sıralamadaki yerlerine ve ayrıca ilgilendikleri bilim dalları ile ilgili sıralamalarına dikkat ettiğini göstermiştir (URAP, 2018a, s.2). Dünya genelinde üniversiteleri sıralamada öne çıan ölçütler şöyledir: Akademik Performans Araştırma Laboratuvarına Göre Üniversite Sıralaması (URAP), Cybermetric Laboratuarları Web'de Dünya Üniversitelerinin Sıralaması (Webometrics), Scimago Enstitüleri Siralaması (SIR), US NEWS Siralaması, Times Dergisi Yükseköğretim Sıralaması (THE), Leiden Üniversitesi Küresel Üniversite Sıralaması (CWTS), Harward Üniversitesi tarafından yapılan Round University Ranking (RUR), QS (Quacquarelli Symonds) dünya üniversite sıralaması, Dünya Üniversite sıralaması merkezi (CWUR) Shanghai Üniversitesi Dünya Üniversiteleri Akademik Sıralaması (ARWU). Bu sıralamalarda kullanılan yöntemler ve kullanılan göstergelerin yapısı, sayısı ile ağırlıklandırılmaları arasında büyük farklılıklar vardır (Lukma et al., 2010). Bu nedenle sıralama yöntemleri ile ilgili ciddi eleştiriler yapılmaktadır (Marginson, 2007):

- $\mathrm{Bu}$ yöntemler göstergelere ilişkin ağırlıklandırma gibi metodolojik sorunları gizlemektedir. Yöntemler bir bileşik endeks oluştururken, üniversitelerin performans ve niteliklerini değişik açılardan ele alarak keyfi ağırlıklandırma uygulamaktadır.

- Sıralama yöntemlerinin uygulandığı yükseköğrenimin tanımı anahtar noktadır. Örneğin Shanghai sıralamasına göre yüksek eğitim bilimsel araştırmadır. Öğretme, toplumu inşa etme, demokrasiyi geliştirme ve yerel veya küresel sorunların çözüm yeri değildir. THE sıralamasına göre yüksek eğitim öncelikle kendi itibarı için tanınmışlık kazanmalıdır.

- Üniversitelerin performanslarına değer biçmek amacıyla geliştirilen göstergelerin nitelikli olması gerekmektedir. Bu sıralamalarda genellikle belli bir metodolojinin veya göstergenin seçilme nedeni, nasıl kurgulandığı, kim tarafından karar verildiği, göstergelerin karar sürecine ne kadar yansıdığı ve ne ölçüde şeffaf oldukları açık değildir.

- Üniversiteleri sıralama yöntemlerini düzenlemek üzere 2004 yılında Unesco Yükseköğrenim için Avrupa Merkezi (Unesco- Eupean Centre for Higher Education: UNESCO-CEPES) tarafından Budapeşte'de kurulan Uluslararası Sıralama Uzmanlık Grubu (International Ranking Expert Group: IREG) 2006 yllında göstergeler ve metodolojik açıdan üniversitelerin sıralanmasına yönelik "Berlin İlkeleri" olarak adlandırılan ilkeleri yayınlamıştır. Buna göre sıralama ve lig tabloları şöyle olmalıdır; 
- Sıralamanın amacı ve hedefleri açısından; yükseköğrenimin girdilerini, sürecini ve çıktılarını değerlendirmede farklı yaklaşımlardan biri seçilmelidir. Sıralama yükseköğrenimin daha iyi anlaşılmasını ve rekabetçi bilgiyi sağlamalı, ancak yükseköğrenimin ne olduğunu ve ne yapacağını değerlendirecek bir yöntem olmamalıdır. Hedef grupları ve amaçları açık olmalıdır. Göstergeler belli bir amaca yönelik olarak tasarlanmalıdır. Kurumların farklı görev ve amaçlarını dikkate alan ve kurumların çeşitliliğini tanıyan bir sıralama yapılmalıdır. Sıralamada kullanılan bilgi kaynaklarının çeşitliliği sağlanmalıdır. Eğitim sistemlerini sıralamada kültürel, ekonomik, dil ve tarihi koşulları belirtmelidir.

- Göstergelerin ağırlıklandırılması ve tasarımı açısından; seçilen göstergelerin önemi ve geçerliliği, farklı göstergelere atanan ağırlıklar ile sıralamayı oluşturmak için kullanılan yöntem açısından şeffaf olmalıdır.

- Veri derleme ve işleme süreci açısından; denetlenebilir ve doğrulanabilir olması, bilimsel veri toplama süreçlerine uygun olması ve sıralama sürecinin kendisine kalite güvencesi ölçütlerinin uygulanabilir olması gerekir.

- Sıralama sonuçlarının sunumu açısından; kullanıcıların sıralamayı geliştirmekte kullanılan bütün faktörleri net bir şekilde anlamasını sağlamalı, göstergelerin nasıl ağırlıklandırıldığını sunmalı, derleme hatalarını azaltmalıdır.

- $\mathrm{Bu}$ genel ilkelere uyulmakla birlikte, üniversitelerin ulusal ve uluslararası sıralamaları genellikle kullanılan göstergeler, kapsam ve sıralama sonuçları açısından birbirinden farklıdır. Uluslararası sıralamalarda daha az gösterge kullanılırken, ulusal sıralamalarda çok daha fazla gösterge kullanılmaktadır. Ulusal ve uluslararası sıralama sistemleri karşılaştırıldığında, sıralama göstergeleri ile ilgili nitelik farklılıklarının da olduğu görülmüştür. Uluslararası sırlamalar daha ziyade bibliyometrik göstergelere dayanmakta ve ulusal sıralamaların aksine üniversitelerin eğitim ve kamu hizmeti gibi diğer önemli görevlerini dikkate almamaktadır. Ulusal sıralamalarda kurumların finansal kaynakları, öğrencilerin ve akademisyenlerin nitelikleri gibi göstergelere de yer verilmektedir (Çakır ve diğerleri, 2015).

- Türkiye'de URAP biri uluslararası ve diğeri ulusal olmak üzere iki üniversite sıralaması yapmaktadır. Uluslararası sıralamada 3000 civarındaki yükseköğretim kurumunun akademik performanslarına ait verileri derleyerek, en yüksek sıradaki 2500 üniversiteyi derecelendirmektedir. Böylece dünyadaki yükseköğretim kurumlarının yaklaşık \% 12'sini değerlendirmektedir. URAP tarafından dünya üniversitelerinin sıralamasında kullanılan 6 gösterge kullanmaktadır. Bu göstergeler (URAP,2018b );

- Toplam derecelendirmede \% 21 ağırlığa sahip olan ve mevcut bilimsel üretkenliği ölçmeyi amaçlayan makale sayısı,

- Toplam derecelendirmede \% 21 ağırlığa sahip olan ve araştırmanın etkisini ölçmeyi amaçlayan atıf sayısı,

- Toplam derecelendirmede \% 10 ağırlığa sahip olan ve uzun süreli üretkenliği ölçmeyi amaçlayan toplam bilimsel doküman sayısı,

- Toplam derecelendirmede \% 18 ağırlığa sahip olan ve kurumların tüm alanlardaki bilimsel üretkenliğini ölçmeyi amaçlayan toplam dergi etki faktörü, 
- Toplam derecelendirmede \% 15 ağırlığa sahip olan ve kurumların tüm alanlardaki bilimsel etkisini ölçmeyi amaçlayan toplam dergi atıf etkisi faktörü ve

- Toplam derecelendirmede \% 15 ağırlığa sahip olan ve kurumların uluslararası itibarı ölçmeyi amaçlayan uluslararası işbirliği ölçütü

şeklindedir. $\mathrm{Bu}$ ölçütlerle oluşturulan toplam puanların en yükseği 600 puandır. URAP tarafından dünya üniversitelerini sıralamada kullanılan ölçütler için veri kaynağ 1 ise WoS (Web of Science) ve InCites'dir (URAP, 2018b). Akademik verimliliği ölçmeyi amaçlayan URAP, uluslararası sıralamada yalnızca araştırma ile ilgili göstergeleri dikkate almakta ve öğretim ile ilgili göstergelere yer vermemektedir. URAP'ın kullandığı bu göstergeler, mutlak değerde olup, üniversitelerin büyüklügüne bağlıdır. Bunun sonucu olarak büyük üniversitelerden yana sapmalıdır. Ayrıca atıf sayısı ve yayın sayısı göstergeleri itibariyle tabi bilimler ve özellikle tıp alanına doğru çarpıktır (Rauhvargers, 2013, s. 66).

Türk üniversiteleri URAP dünya siralamasında 2010/2011 döneminde 63 üniversite ile yer alırken, 2017/2018 döneminde 86 üniversite ile yer almaktadır. 2010/2011 yılında 314,72 puan alan Hacettepe Üniversitesi 399. sıradan listeye girerek, Türk üniversiteleri içinde birinci sırayı alırken, sonuncu sırada 43,26 puan ile Doğuş Üniversitesi olmuştur. 2017/2018 döneminde sıralamadaki en yüksek puanlı üniversite 316,31 puan ile 532. sırayı alan ODTÜ olmuş, sonuncu üniversite ise 37.21 puan ve 2488. sıradaki İzmir Ekonomi Üniversitesidir. Son dönemlerde ise Türk üniversitelerinin URAP dünya sıralamasında ilk 500 üniversite arasındaki yerlerini kaybettiği ve ancak ilk 1000 üniversite arasında yer aldığı görülmüştür.

URAP, Türkiye'deki üniversiteleri sıralamada, dünya üniversitelerini sıralamada kullandığından biraz daha farklı göstergelerden yararlanmaktadır. URAP’ın Türkiye sıralamasında eşit ağırlıklı olarak kullanılan göstergeler ise,

- Makale sayısı,

- Öğretim üyesi başına düşen makale sayısı,

- Atıf sayısı,

- Öğretim üyesi başına düşen makale sayısı,

- Atıf sayısı, öğretim üyesi başına düşen atıf sayısı,

- Toplam bilimsel doküman sayısı,

- Öğretim üyesi başına düşen toplam bilimsel doküman sayısı,

- Doktora öğrenci sayısı, doktora öğrenci oranı ve

- Öğretim üyesi başına düşen öğrenci sayısıdır.

URAP Türkiye (URAP-TR) sıralama göstergelerinden makale puanı sıralamanın yapıldığı yıldan bir önceki yılın makale sayısı puanı ile bir önceki yılda öğretim üyesi başına düşen makale sayısı puanı toplanarak bulunur. Atıf puanı da benzer şekilde bir önceki yılda son beş yılda yayınlanan makalelere yapılan atıf sayısı puanı ile öğretim üyesi başına son beş yılda düşen atıf sayısı puanı toplanarak bulunur. Toplam bilimsel doküman puanı son beş yılda yapılan toplam bilimsel doküman sayısı puanı ile öğretim üyesi başına düşen toplam bilimsel doküman sayısı puanı toplamıdır. Doktora öğrencisi puanı, doktora öğrencisi sayısının toplam öğrenci içindeki 
yüzdelik puanı ile toplanarak bulunur. Öğrenci sayısı/ öğretim üyesi sayısı puanı ise öğretim üyesi başına düşen öğrenci sayısı puanıdır (URAP, 2018a). URAP-TR göstergeleri hem üniversite büyüklüğüne bağll, hem de üniversite büyüklüğünden bağımsız göstergelerdir. Üniversite büyüklüğüne bağlı göstergeler büyük üniversitelerden yana sapmalıyken, büyüklükten bağımsız göstergeler küçük ancak üretken üniversitelerden yana sapmalıdır. Büyüklük etkisindeki göstergeler kareli logaritmik dönüştürme ile kullanılmaktadır. Göstergeler ayrıca akademik performansın sürekliliğini de dikkate almaktadır. Böylece URAPTR Türk üniversitelerini sıralamada en adil sistemi bulmaya çalışıı̧tır (Alaşehir ve diğerleri, 2014).

Türkiye sıralamasında kullanılan göstergeler WoS, YÖK ve ÖSYM'den derlemektedir. Bu göstergeler araştırma üniversitelerinin sahip olması gereken nitelik ve amaçlarla birebir uyumludur. Ancak göstergelerin eşit ağırlıklı olarak kullanılması Özbaşı ve Uslu (2018) tarafından eleştirilmiştir. Özbaşı ve Uslu (2018) çalışmalarında keşfedici faktör analizi ile belirlenen faktörlere uyguladıkları regresyon analizi kullanarak göstergelere ağırlık belirlemiştir.

\section{Literatür Analizi}

Literatürde üniversiteler arasındaki farkı, üniversitelerin araştırma çıktılarına bağlı olarak inceleyen pek çok çalışma vardır. Bu çalışmalardan önemli bir kısmı istatistiksel yöntemlere dayanmaktadır. Avkıran (2001) veri zarflama analizi ile Avustralya üniversiteleri arasındaki teknik ve ölçek etkinlik farklarını, Erdoğmuş ve Esen (2016) hiyerarşik kümeleme analizi ile Türk üniversitelerinin kümelenmesini incelemiştir.

Al Şahiner ve Tonta (2006), bibliyometrik analiz ile Türkiye'deki üniversitelerin sanat ve beşeri bilimler alanlarına katkılarını araştırmışlardır. Selvitopu ve Aydın (2018) çalışmalarında THE veri tabanında ilk 100 üniversite arasındaki 8 Türk üniversitesini çeşitli göstergelerden hareketle içerik analizi ile değerlendirilmiştir. Erkoç (2016), Türkiye'deki kamu üniversitelerinin veri zarflama analizini kullanarak teknik ve maliyet etkinliklerini incelemiştir. Elde ettikleri sonuçlara göre üniversitelerin bazı istisnalar dışında iyi olmadığını ifade etmişlerdir. Bu çalışmada ayrıca tobit regresyon ile üniversitelerin bünyelerinde tıp fakültesi barındırmalarının performansı etkileyip etkilemediğini de araştırmışlardır.

Eğitim eşitsizliğinin incelendiği çoğu çalışmada ise Gini katsayına yer verilmiştir. Tomul (2009), Türkiye'de eğitim eşitsizliği ile 25 yaş üstü nüfusun ortalama okulda kalma yılı arasındaki ilişkiyi eğitim eşitsizliğini ölçmek için geliştirilen Gini katsayısı ile araştırmıştır. Sonuç olarak ortalama okulda kalma yılı ile eğitim eşitsizliğini ölçen Gini katsayısı arasındaki ilişkinin ters yönlü olduğunu göstermiştir.

Halffman ve Leydesdorff (2010) çalışmalarında 2003-2008 yılları arasındaki üniversite sıralamalarını dikkate alarak çeşitli ülkeler için Gini katsayısını hesaplamışlardır. Yazarlar Gini katsayılarını hesaplarken, 2003-2008 yılları arasındaki ilk 500 üniversiteden hareket etmişlerdir. Gini katsayısı ile üniversiteler arasındaki eşitsizliği ele alan bir diğer çalışma ise Kore’deki 184 
üniversitenin 2009-2015 yılları arasındaki farkın açılıp açılmadığını değerlendiren Jeon ve Kim (2018)'e aittir. Ville ve diğerleri (2006), 1992-2003 yılları arasında Avustralya Üniversitelerinin farklı araştırma performansları için Gini katsayısını hesaplamıştır. Çalışmada araştırma girdilerinin dağılımının düzensiz olduğu, ancak araştırma çıktılarının dağılımının düzgün olduğu belirlenmiştir. Bornmann ve diğerleri (2008), Zürih Üniversitesinde bilimsel araştırmaları değerlendirmede atıf sayısı esas alarak yaptıkları çalışmada araştırma gruplarının yayın performansını karşılaştırırken, istatistiksel yöntem olarak kutu gösterimi, Lorenz eğrisi, Gini katsayısından yararlanmıştır. Bu yöntemleri uygularken farklı referans standartlarını ele alarak, bu standartların uygunluklarını da sınamıştır. Huanga ve diğerleri (2012) dünya genelinde teknolojik yeniliklerdeki ve bilimsel araştırmadaki yoğunlaşma trendini yayın, patent sayısı, patent ve yayınlara yapılan atıfları kullanarak, Herfindahl- Hirschman endeksi (HHI) ve Gini Katsayısı yardımıyla ölçmüştür. Çalışmada Gini ve HHI’inin benzer sonuçlar verdiği sonucuna ulaşmıştır.

Abroma ve diğerleri (2009) ise İtalyan üniversitelerinde 2004-2008 yılları arasında bibliyometik göstergeleri kullanarak akademik unvanlar ile bireysel araştırma verimliliği arasındaki ilişkiyi incelemiştir. Akademik unvanlar ve üniversite disiplin alanları arasındaki Gini katsayılarını hesaplamış ve dağılımın bir piramit oluşturmadığı daha ziyade düzgün dağılım olduğu, ancak profesörler lehine çarpık olduğu sonucuna varmıştır. Garcia ve Medina (2014) üniversiteler için bibliyometrik yöntemlerle yapılan bilimsel alan sıralamasını iki İspanyol üniversitesinin 37 disiplini üzerinden, Thomson Scientific (TS) ve I-UGR sıralama ölçütünü kullanarak incelemiştir. TS ve I-UGR'in bilim alanları sıralamalarını Gini katsayısı ile kıyaslamıştır.

Dünya literatüründe üniversitelerin araştırma çıktıları arasındaki eşitsizliği ölçmek üzere Gini katsayısının kullanıldığı pek çok yayın olmasına rağmen, yapılan taramada Türkçe literatürde bu yöntemin kullanıldığı bir araştırmaya rastlanmamıştır. Üstelik Türk üniversitelerinin araştırma çıktılarını inceleyen çalışmalar genellikle süreklilik göstermemektedir. Her çalışma farklı göstergeleri incelemektedir.

\section{Yöntem}

Çalışmada üniversiteler arasındaki eşitsizliği ölçmekte Gini katsayısından yararlanılmıştır. Gini Katsayısı İtalyan istatistikçi Corrado Gini tarafından toplumdaki gelir eşitsizliğini ölçmek üzere geliştirilmiştir. Genellikle Max Lorenz tarafından tanıtılan servet yoğunluğunun grafiği ile ilişkilendirilerek kullanılmaktadır. Bu ölçüler servet ve gelirden farklı konularda da kullanılmaktadır. Eşitsizlik ölçüsü olan Gini, ilgili ölçütler için sıralı ikililer arasındaki mutlak farkların ortalaması olarak tanımlanmaktadır. Gini katsayısı, bir sıklık dağılımının eşitsizlik miktarını ölçen ve 0 ile 1 arasında değerler alan bir katsayıdır. Gini katsayısının yüksek değerleri sıralanan birimler arasında büyük bir eşitsizlik olduğunu gösterirken, düşük değeri birimler arasındaki eşitsizliğin azaldığı anlamına gelmektedir. Katsayının sıfıra eşit olması ölçülen bütün birimlerin birbirine eşit olduğu anlamına gelir. Gini katsayısı gelir dağılımının Lorenz eğrisine dayandığında, anakütleden rastlantısal olarak seçilen iki birim arasındaki beklenen gelir farkı olarak yorumlanmaktadır. Gini katsayısı bağıl ortalama farklara bağlı olarak; 
$G=\frac{1}{2 \mu n^{2}} \sum_{i=1}^{n} \sum_{j=1}^{n}\left|y_{i}-y_{j}\right|$

şeklinde tanımlanır. Burada y gözlenen değer, $\mu$ ortalama, $\mathrm{n}$ gözlenen değerlerin sayısı, $i$ ise değerlerin yükselen sırada farklarını gösterir. Hesaplamalarda yalnızca sıfırdan farklı pozitif değereler kullanılmaktadır.

Gini katsayısı bir örneklem istatistiği olduğundan, örneklem varyansına ve dolayısıyla standart hataya sahiptir. Gini katsayısının küçük örnek varyans özellikleri bilinmezken, büyük örneklerde varyans özellikleri zayıftır. Bu nedenle güven aralıkları yeniden örnekleme yöntemi ile hesaplanmalıdır. Gini katsayısının sapmasız varyans ve standart hatasının hesabında jackniffe tekniğine başvurulur (Giles, 2004). Buna göre Gini’nin jackknife varyansı;

$\operatorname{Var} G=\left(\frac{n-1}{n}\right) \sum_{k=1}^{n}[G(n, k)-\bar{G}(n)]^{2}$

şeklindedir. Burada G(n,k) , k. Gözlem çıkarıldıktan sonra kalan (n-1) gözleme dayanan Gini katsayısının sahte (pseudo ) tahminidir. $\bar{G}(n)$ ise bütün $\mathrm{G}(\mathrm{n}, \mathrm{k})$ 'ların aritmetik ortalamasıdır. Böylece anakütle varyans değerinin sapmasız tahminleri elde edilir. Buradan jackknife standart hata $\left(\hat{\sigma}_{G}\right)$, varyansın karekökü alınarak bulunur (Ogwang, 2000). Gini katsayısının güven aralıkları için bootstrap yöntemi ile ampirik dağılımdan yararlanılarak hesaplanır. Gini katsayısının olasılık dağılımı özellikle küçük örneklerde normal dağılıma yaklaşmadığından, yüzdelik (percentile) bootstrap yöntemiyle, ampirik dağılımın $\alpha / 2$ ve (1- $\alpha / 2)$ 'lik yüzdelerinden (1- $\alpha$ ) güven düzeyinde güven aralıkları tahmin edilir. Böylece tahmin edilen yüzdeliklere $q_{\alpha / 2}$ ve $q_{1-\alpha / 2}$ denirse; bootstrap güven aralıkları;

$G-\hat{\sigma}_{G} q_{1-\frac{\alpha}{2}} ; G-\hat{\sigma}_{G} q_{\frac{\alpha}{2}}$

olur (Davidson, 2009).

Lorenz eğrisi de Gini katsayısı gibi gelir dağılımındaki eşitsizliği açıklamak amacıyla kullanılmaktadır. Burada ise üniversiteler arasındaki eşitsizliği açıklamakta kullanılacaktır. Buna göre yatay eksende üniversitelerin birikimli sıralamasının, dikey eksende ise üniversitelerin ilgili çıktılarının birikimli yüzde payları (her bir üniversitenin çıktısındaki artışı) yer aldığı bir grafikte Lorenz eğrisi, bütün üniversiteler eşit ise, mutlak eşitlik doğrusu olarak adlandırılan $45^{\circ}$ lik doğru üzerinde olur. En uç durumda sistemdeki tüm çıtıları tek bir üniversite üretir. Böyle bir durumda eğri, X eksenini en son noktasına kadar takip eder. Lorenz Eğrisi, mutlak eşitlik doğrusuna yaklaştıkça üniversiteler arasındaki çıktı farkının azaldığı, uzaklaştıkça ise bu farkın arttı̆̆ ş̧eklinde yorumlanır. Gini katsayısı Lorenz eğrisinin alanının mutlak eşitlik doğrusunun altında kalan bütün alana oranlanması ile elde edilmektedir. 


\section{Veri Kümesi ve Uygulama}

Çalışmada ilk olarak URAP-TR sıralama ölçütleri olan makale ve atıf puanı, bilimsel doküman puanı, doktora öğrenci puanı, öğrenci sayısı/ öğretim üyesi ve toplam puanlarla yapılan sıralamaların her biri için ayrı ayrı Gini katsayısı hesaplanmıştır. Ancak 2010/2011 döneminde makale puanı yerine toplam yayın puanı ve doküman puanı yerine GS puanı adıyla 2001-2009 yılları arasında Google-Scholar tarama puanları ile öğretim üyesi başına düşen Google Scholar tarama puanları toplamı alınmıştır. URAP -TR sıralamasına 2010-2018 yılları arasında her yıl farklı sayıda üniversite girmiştir. Yıllar arasında kıyaslama yapabilmek için her yıl sürekli olarak sıralamaya giren 121 devlet ve vakıf üniversitesi ele alınarak, bu üniversitelere ait Gini katsayıları hesaplanmıştır. Ancak daha önce söz konusu üniversitelerin puanlarına ait dağılımların özellikleri, URAP-TR sıralamasına konu olan değişkenlerin her biri için kutu diyagramı ile incelenmiştir. Kutu gösterimi bir dağılımı özetlemekte kullanılan görsel bir yoldur. Gösterim sıralanmış bir dağılımın dörde bölenleri üzerinden yapılmaktadır. Oluşturulan kutunun alt sınırını birinci, üst sınırını ise üçüncü dörde bölen oluştururken, bu dörde bölenlerin medyandan farklarına bağlı olarak dağılımın çarpıklığı belirlenir. Kutunun alt ve üstüne eklenen doğrular, kutudan 11/2 dörde bölenler arası fark kadar uzaktaki gözlemleri temsil eder. Bu gösterimde doğrulardan daha uzakta kalan tüm değerler aykırı gözlem olarak kabul edilir. Buna göre sırasıyla makale puanı, atıf puanı, doküman puanı, doktora öğrencisi puanı, öğrenci sayısı/öğretim üyesi puanı ve toplam puanları kutu diyagramları ile Şekil 1'de gösterilmiştir. 

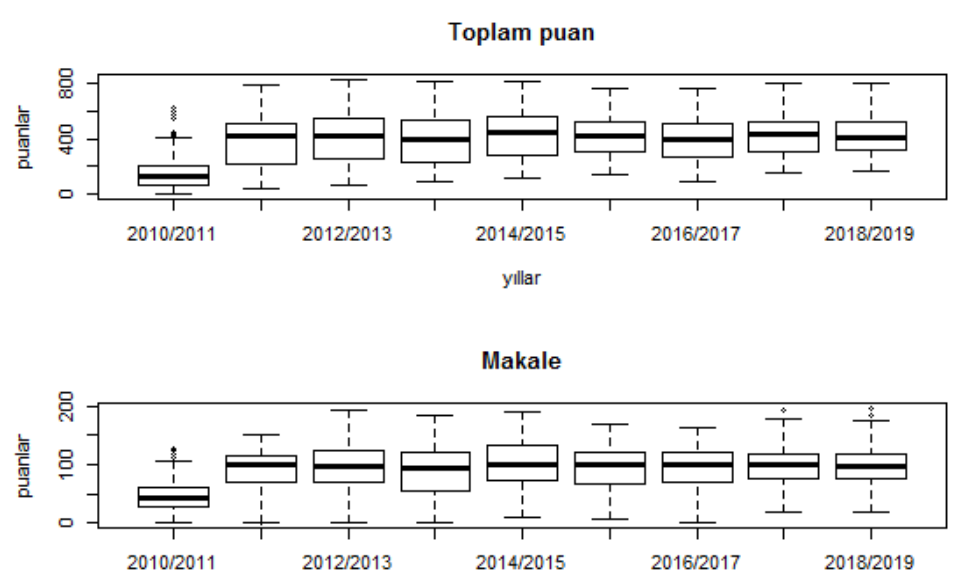

yillar

Atıf

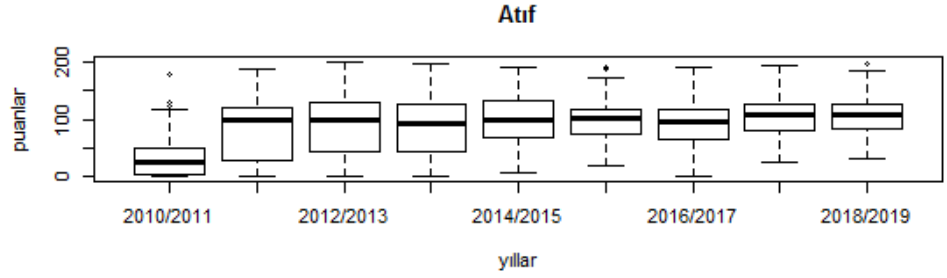

Dokuman

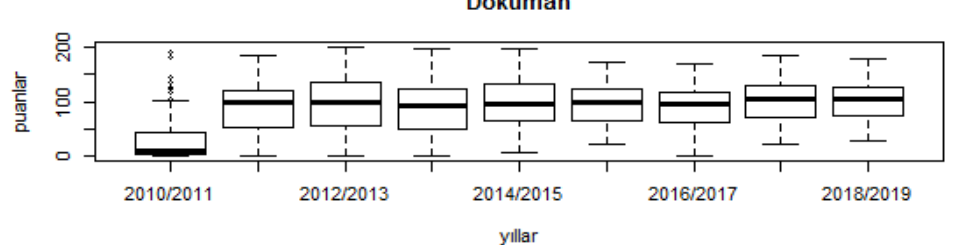

Doktora

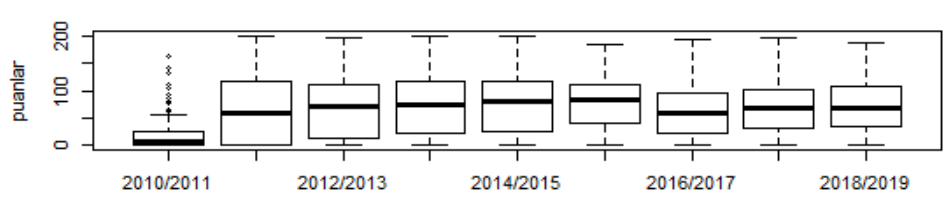

yillar

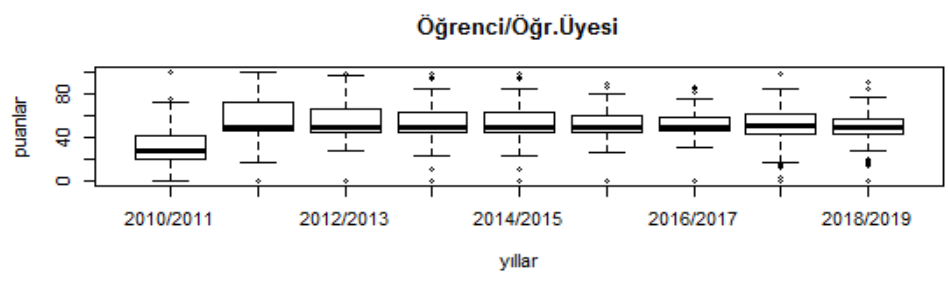

Şekil 1. URAP-TR Kriterlerine Göre Kutu Diyagramları

Buna göre makale puanları açısından üniversitelerimizin 2011/2012, 2013/2014 ve 2015/2016 dönemlerinde en çarpık dağılıma sahip olduğu, ancak özellikle 2017/2018 dönemi itibariyle dağılımın simetrikleştiği görülmektedir. 2014/2015 ve 2018/2019 dönemleri hariç makale puanı dağılımları sola çarpıktır. 2010/2011 döneminde toplam yayın puanları açısından sırasıyla Orta Doğu Teknik Üniversitesi, Ankara Üniversitesi, İstanbul Üniversitesi ve Hacettepe Üniversitesi aykırı gözlem niteliğindedir. Aynı şekilde 2017/2018 döneminde makale puanı açısından Orta Doğu Teknik Üniversitesi aykırı gözlemdir. Üniversitelerin atıf puanlarına gelince, ders yılları 
itibariyle dağılımın 2010/2011 ve 2014/2015 dönemlerinde sağa çarpık olmakla birlikte, diğer yıllarda sola çarpık olduğu görülmüştür. Son dönemde ise simetrikleşmiştir. Atıf puanları açısından da 2010/2011 döneminde sırasıyla İhsan Doğramacı Bilkent, Orta Doğu Teknik ve Hacettepe Üniversiteleri aykırı gözlem konumundadır. 2015/2016 döneminde de yine İhsan Doğramacı Bilkent, Orta Doğu Teknik Üniversiteleri aykırı gözlem konumundadır. Üniversitelerin doküman puanlarına ait dağılımlarının 2010/2011 ve 2014/2015 dönemlerinde sağa çarpık, diğer dönemlerde sola çarpık olduğu söylenebilir. 2014/2015 dönemi makale, atıf ve doküman sayısı açısından hemen hemen simetrik bir dağılıma sahiptir. Doktora öğrenci puanlarına bakıldığında, yine 2010/2011 dönemi hariç tüm dönemler itibariyle dağılımların sola çarpık olduğu, son dönem olan 2018/2019 döneminde simetrikleştiği, 2010/2011 döneminin en çarpık dağılıma sahip dönemin ve bu dönemde 11 üniversitenin aykırı gözlem durumunda olduğu belirlenmiştir. Bu dönemdeki 121 üniversitenin yaklaşık \%41'inde hiç doktora öğrencisi olmaması, bu veri kümesinde aslında iki kitle resminin olduğu sonucuna götürmektedir. Üniversitelerin öğretim üyesi başına düşen öğrenci puanına ait dağılımın tüm yıllarda sağa çarpık ve her dönemde fazlasıyla aykırı gözleme sahip olduğu görülmektedir. Toplam puanlar dağılımının ise 2016/2017 dönemi hariç tüm dönemlerde sola çarpık, 2015/2016 döneminden itibaren simetrikleştiği görülmektedir. Genel olarak 2010/2011 döneminde tüm göstergeler için medyan değerinin diğer yıllara kıyasla en düşük olduğu ve 2011/2012 döneminden itibaren medyan değerinin bütün dönemlerde birbirine yakın seyrettiği görülmüştür. Dörde bölenler aralığının da en dar olduğu dönemin 2010/2011 dönemi olduğu ve son iki dönemde yeniden daralmaya başladı̆̆ı belirlenmiştir.

\section{Bulgular}

URAP sıralamasına göre Türk üniversitelerinin Gini katsayısı hesaplanarak sonuçlar Tablo 1'de verilmiştir. Tabloya göre 2011/2012 döneminin bütün üniversiteler için araştırma çıktılarını iyileştirmekte bir dönüm noktası olduğu söylenebilir. Ancak bu noktada 2010/2011 döneminde yayın sayısındaki ve doküman puanındaki hesaplama değişikliği unutulmamalıdır. Tabloya göre 2010/2011 döneminde üniversiteler arasında eşitsizliğe neden olan en önemli gösterge \%72 ile üniversitelerin doktora öğrencisi sayısıdır.

Tablo 1. URAP-TR Göstergelerine Göre 121 Üniversitenin Gini Katsayıları

\begin{tabular}{|l|l|l|l|l|l|l|l|l|l|}
\hline $\begin{array}{l}\text { Yillar } \\
\text { Gösterge }\end{array}$ & $\begin{array}{l}\mathbf{2 0 1 0 /} \\
\mathbf{2 0 1 1}\end{array}$ & $\begin{array}{l}\mathbf{2 0 1 1 /} \\
\mathbf{2 0 1 2}\end{array}$ & $\begin{array}{l}\mathbf{2 0 1 2 /} \\
\mathbf{2 0 1 3}\end{array}$ & $\begin{array}{l}\mathbf{2 0 1 3 /} \\
\mathbf{2 0 1 4}\end{array}$ & $\begin{array}{l}\mathbf{2 0 1 4 /} \\
\mathbf{2 0 1 5}\end{array}$ & $\begin{array}{l}\mathbf{2 0 1 5 /} \\
\mathbf{2 0 1 6}\end{array}$ & $\begin{array}{l}\mathbf{2 0 1 6 /} \\
\mathbf{2 0 1 7}\end{array}$ & $\begin{array}{l}\mathbf{2 0 1 7 /} \\
\mathbf{2 0 1 8}\end{array}$ & $\begin{array}{l}\mathbf{2 0 1 8 /} \\
\mathbf{2 0 1 9}\end{array}$ \\
\hline Makale $^{*}$ & 0.33 & 0.21 & 0.23 & 0.29 & 0.23 & 0.22 & 0.22 & 0.21 & 0.21 \\
\hline Atıf & 0.56 & 0.36 & 0.32 & 0.32 & 0.24 & 0.20 & 0.24 & 0.20 & 0.19 \\
\hline Doküman $^{\star}$ & 0.64 & 0.28 & 0.27 & 0.30 & 0.25 & 0.20 & 0.25 & 0.20 & 0.19 \\
\hline Doktora & 0.72 & 0.51 & 0.46 & 0.43 & 0.41 & 0.33 & 0.41 & 0.38 & 0.37 \\
\hline Öğrenci/Öğr.Üye & 0.31 & 0.19 & 0.17 & 0.17 & 0.17 & 0.13 & 0.12 & 0.18 & 0.15 \\
\hline Toplam Puan & 0.41 & 0.27 & 0.25 & 0.27 & 0.22 & 0.19 & 0.22 & 0.20 & 0.19 \\
\hline
\end{tabular}

*2010/2011 ylında URAP-TR tarafından makale puanı yerine toplam yayın puanı ve doküman puanı yerine GS (Google-Scholar) Puanı hesaplanmıştır.

Üniversiteler arası eşitsizlik açısından doktora öğrencisi göstergesini 2010-2011 döneminde \%64 ile doküman puanı ve \% 56 ile atıf puanı izlemektedir. Ancak üniversiteler arasındaki eşitsizliğin, 2011/2012 döneminden sonra bütün göstergelerde hızla iyileştiği 
görülmektedir. 2011/2012 döneminin bütün üniversiteler için araştırma çıktılarını iyileştirmekte bir dönüm noktası olduğu söylenebilir. Bunun bir nedeninin üniversitelerin sıralama ölçütlerine uygun çalışmalar üretmesi olduğu, diğer bir nedenin ise hesaplama yöntemindeki değişimin etkisi olduğu düşünülmektedir. Yine de bu hızlı iyileşmeye rağmen, incelenen son dönemler 2017/2018 ve2018/2019 döneminde eşitsizliğin en yüksek olduğu göstergenin sırasıyla \% 38 ve \% 37 ile mezun edilen doktora öğrencisi sayısı olduğu belirlenmiştir. Diğer göstergeler incelendiğinde, makale puanı açısından üniversitelerin inceleme döneminin başından itibaren birbirine daha yakın olduğu görülmektedir. Bu durum öğrenci sayısı/ öğretim üyesi açısından da geçerlidir. Bu göstergede üniversiteler arası eşitsizlik 2010/2011 dönemi haricinde \% 20'nin altında seyretmiştir. Hatta tüm göstergeler arasında üniversiteler arasındaki eşitsizliğin en azaldığı gösterge ise 2018/2019 döneminde \% 15 ile öğrenci sayısı /öğretim üyesi göstergesidir. Sonuç olarak genelde üniversiteler arasındaki farkın hızla kapandığı ve Gini katsayısının 2012/2013 döneminden itibaren bütün göstergelerde 0.5'nın altında olduğu ve 2018/2019 döneminde doktora öğrencisi sayısı hariç bütün göstergelerin \%20 civarında olduğu görülmüştür. Gini katsayılarına ait bootstrap yöntemi ile \% 95 güven aralıkları hesaplanarak, üniversiteler arasındaki eşitsizlik bir alt ve üst sınırlar 2010/2011, 2011/2012 ve 2018/2019 dönemleri için Tablo 2'de verilmiştir. Güven aralıkları yalnızca ilk ve son dönemler için verilmek istenmiş, ancak ilk dönemde yapılan hesaplama değişikliklerinin etkisi ile 2010/2011 dönemi ile son dönem arasında denge sağlanması amacıyla 2011/2012 döneminde de güven aralıkları hesaplanmıştır.

Tablo 2. 2010/2011, 2011/2012 Dönemleri ile 2018 /2019 Dönemine ait Gini Katsayılarının Güven Aralikları

\begin{tabular}{|l|l|l|l|l|l|l|}
\hline \multirow{2}{*}{ Gı̈stergeler } & \multicolumn{2}{c|}{ 2010-2011 } & \multicolumn{2}{c|}{$2011 / 2012$} & \multicolumn{2}{c|}{$2018 / 2019$} \\
\cline { 2 - 7 } & Alt sınır & Üst Sınır & Alt sınır & Üst Sınır & Alt sınır & Üst Sınır \\
\hline Makale & 0.3049 & 0.3538 & 0.1872 & 0.2295 & 0.1905 & 0.2248 \\
\hline Atıf & 0.5268 & 0.5921 & 0.3268 & 0.3866 & 0.1701 & 0.2011 \\
\hline Doküman & 0.6098 & 0.6666 & 0.2521 & 0.3007 & 0.1801 & 0.2082 \\
\hline Doktora & 0.6862 & 0.7461 & 0.4768 & 0.5487 & 0.3468 & 0.4026 \\
\hline Ö̆g.ci/Ö̆ğr. Üye & 0.2825 & 0.3345 & 0.1719 & 0.1997 & 0.1372 & 0.1683 \\
\hline Toplam Puan & 0.3883 & 0.4374 & 0.2474 & 0.2853 & 0.1776 & 0.1986 \\
\hline
\end{tabular}

*2010/2011 yılında URAP-TR tarafından makale puanı yerine toplam yayın puanı ve doküman puanı yerine GS (Google-Scholar) Puanı hesaplanmıştır.

Tablo 2'den de görüldüğü gibi 2010/2011 döneminde toplam yayın sayısı puanı göstergesinin Gini katsayılarına ait güven aralıkları en dar iken, atıf sayısı puanı ile ilgili Gini katsayısının güven aralığı en geniştir. 2011/2012 döneminde ise en dar aralık öğrenci/öğretim üyesi puanı iken, en geniş aralık doktora öğrencisi puanı ve atıf sayısı puanındadır. 2018/2019 döneminde güven aralıkların tüm göstergeler için son derece daraldığı ve en geniş aralığın beklendiği gibi doktora öğrencisi sayısında olduğu görülmüştür. Bu sonuca göre yıllar içinde göstergelerin eşitsizliğini ölçen Gini katsayısının değişkenliğinin azaldığı ve üniversitelerin tüm göstergelerde birbirine ciddi derecede yaklaştığ 1 söylenebilir.

Üniversitelerin mezun ettiği doktora öğrencisi sayısının diğer göstergelerle kıyaslandığında; üniversiteler arasında daha fazla eşitsizliğe yol açmasının nedeni olarak tıp fakültelerinin mezun 
ettikleri tüm öğrencilerin doktor unvanı kazanması ve bünyesinde tıp fakültesi olan üniversitelerin mezun doktora öğrencisi sayısının diğerlerinden daima daha fazla olması görülmüştür. Tıp fakültelerinde ayrıca kaynak tahsisi ve yayın sayısı da diğer fakültelerden fazladır. Bu nedenle çalışmada bünyesinde tıp fakültesi olan üniversiteler ve olmayan üniversiteler ayrı ayrı incelenerek Gini katsayıları hesaplanmıştır. Bu incelemenin sonuçları Tablo 3'de verilmiştir.

Tablo 3. Bünyesinde Tip Fakültesi Barındıran Üniversiteler ve Diğerlerinin URAP-TR Göstergelerine Göre Gini Katsayıları

\begin{tabular}{|c|c|c|c|c|c|}
\hline \multirow{2}{*}{ Göstergeler } & $2010 / 2011$ & $2011 / 2012$ & $2012 / 2013$ & $2013 / 2014$ & $2014 / 2015$ \\
\hline & Diğer & Diğer & Diğer & Diğer & Diğer \\
\hline Makale* & 0.38 & 0.29 & 0.29 & 0.39 & 0.30 \\
\hline Atıf & 0.71 & 0.52 & 0.44 & 0.44 & 0.30 \\
\hline Doküman ${ }^{\star}$ & 0.74 & 0.37 & 0.33 & 0.39 & 0.31 \\
\hline Doktora & 0.82 & 0.68 & 0.59 & 0.54 & 0.52 \\
\hline Öğrr/Öğ.Üyesi & 0.39 & 0.21 & 0.20 & 0.17 & 0.17 \\
\hline Toplam Puan & 0.47 & 0.34 & 0.30 & 0.33 & $\{0.26$ \\
\hline Yillar & $2015 / 2016$ & $2016 / 2017$ & $2017 / 2018$ & $2018 / 2019$ & \\
\hline Göstergeler & Diğer & Diğer & Diğer & Diğer & \\
\hline Makale & 0.29 & 0.29 & 0.27 & 0.26 & \\
\hline Atıf & 0.27 & 0.31 & 0.26 & 0.24 & \\
\hline Doküman ${ }^{*}$ & 0.25 & 0.32 & 0.24 & 0.23 & \\
\hline Doktora & 0.42 & 0.49 & 0.46 & 0.46 & \\
\hline Ögr/Öğ.Üyesi & 0.15 & 0.13 & 0.23 & 0.20 & \\
\hline Toplam Puan & 0.23 & 0.26 & 0.23 & 0.21 & \\
\hline
\end{tabular}

*2010/2011 yılında URAP-TR tarafından makale puanı yerine toplam yayın puanı ve doküman puanı yerine GS (Google-Scholar) Puanı hesaplanmıştır.

Tablodan da görüldüğü gibi başta atıf puanı ve doktora öğrencisi puanı olmak üzere bütün göstergeler açısından tıp fakültesi olan üniversiteler ile olmayan üniversiteler arasında araştırma çıktıları bakımından daha yüksek bir eşitsizlik bir mevcuttur. Ancak yine de doktora 
öğrencisi puanında, tıp fakültesi olan üniversitelerde de diğer göstergelerden yaklaşık iki katı daha fazla eşitsizlik vardır. Tıp fakültesi olan ve olmayan üniversitelerin araştırma çıktılarına bakıldığında, hemen hemen bütün dönemlerde Gini katsayısı 0.5’nin altındadır. Bu durumda tıp fakültesi olan üniversiteler kendi içinde birbirine benzer, aynı şekilde tıp fakültesi olmayan üniversiteler de kendi içinde birbirine benzer araştırma çıktıları ürettiği sonucuna varılmıştır. Tablo 1 ve Tablo 3'de yer verilen Gini katsayılarını görsel olarak destekleyen Lorenz eğrileri Şekil 2'de yer almaktadır. Eğriler incelendiğinde, 2010/2011 döneminde gerek atıf, gerek doküman ve gerekse doktora öğrencisi sayısı açısından tüm üniversiteler arasındaki çıktı farkının fazla olduğu, 2018/2019 döneminde ise bu çıktı farkının azaldığı, özellikle de bünyesinde tıp fakültesi barındıran üniversiteler grubunun mutlak eşitlik doğrusuna yaklaştığ görülmektedir. Ancak 2018/2019 döneminde de hâlâ eşitsizliğin en fazla olduğu gösterge doktora öğrencisi sayısıdır.
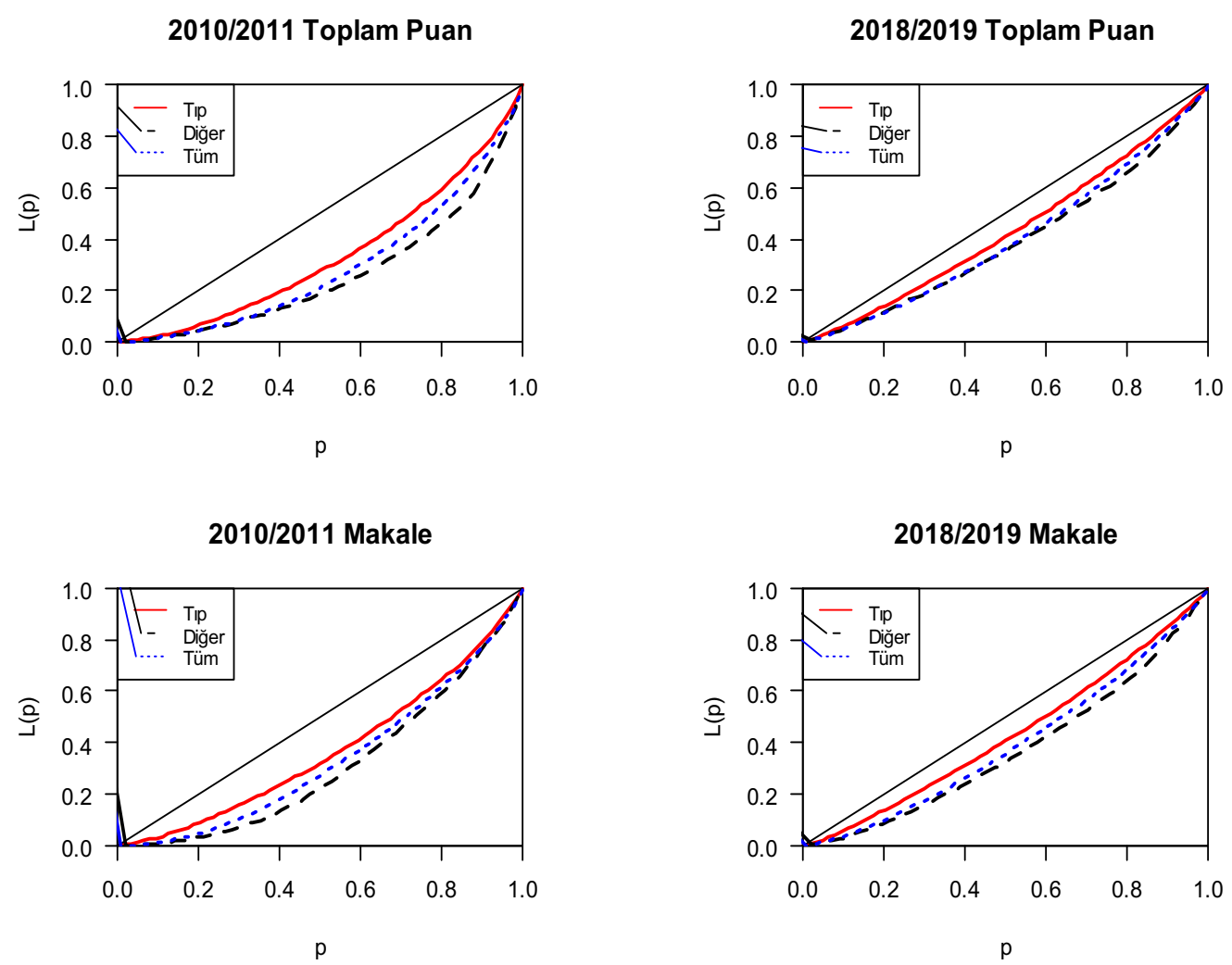


\section{0/2011 Atıf}

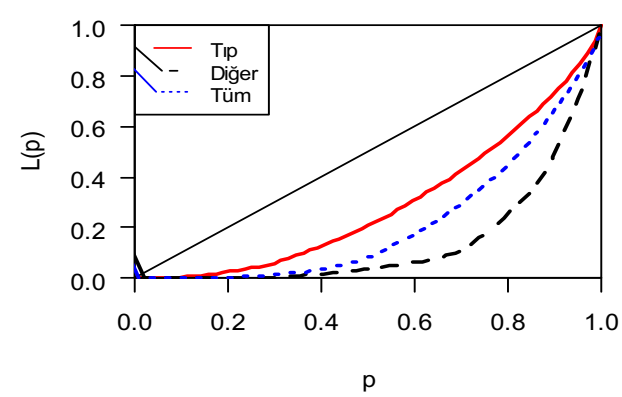

2010/2011 Döküman

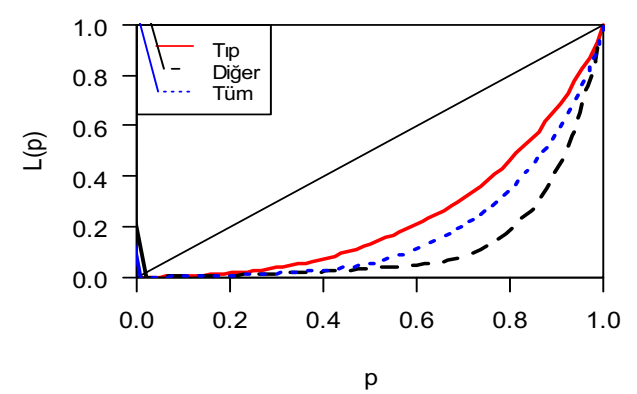

2010/2011 Doktora Öğrencisi

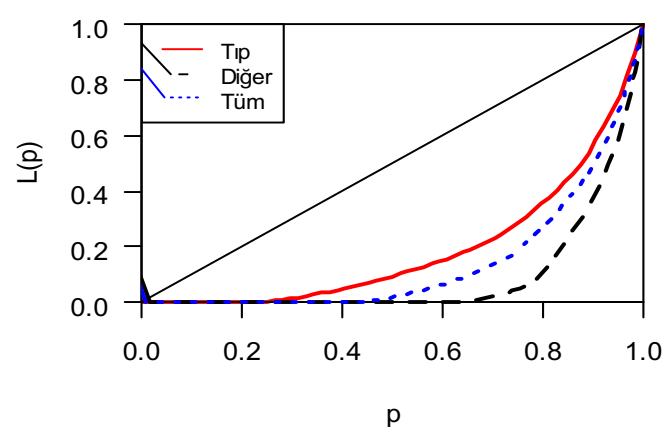

2010/2011 öğrenci/öğr.üye

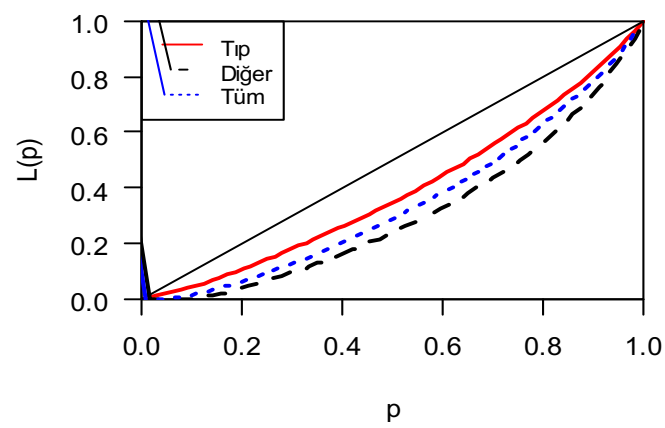

2018/2019 Atıf

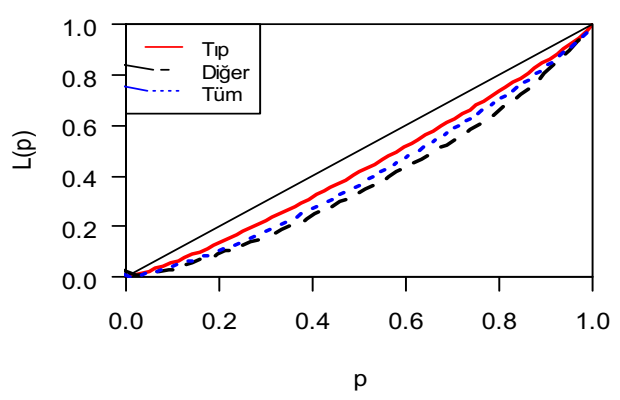

2018/2019 Döküman

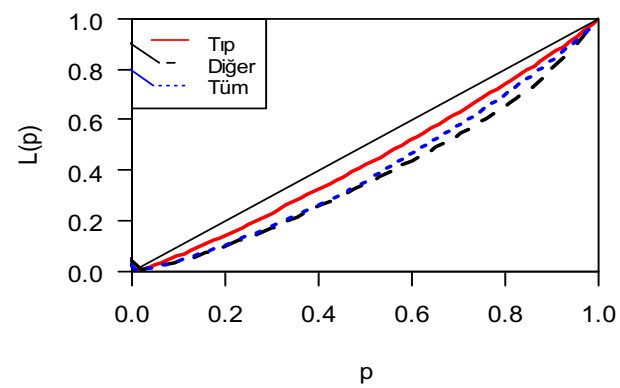

2018/2019 Doktora Öğrencisi

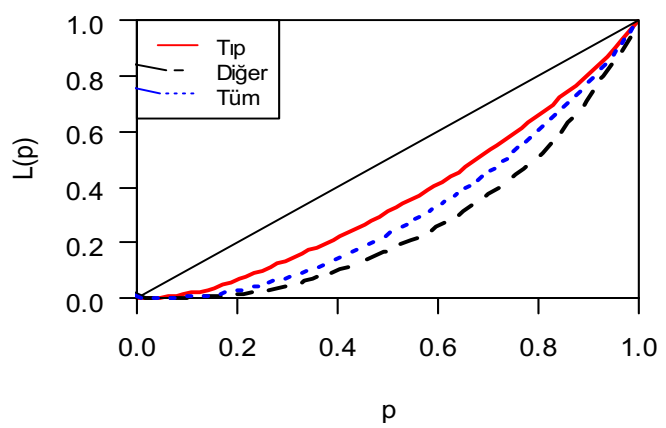

2018/2019 öğrenci/öğr.üyesi

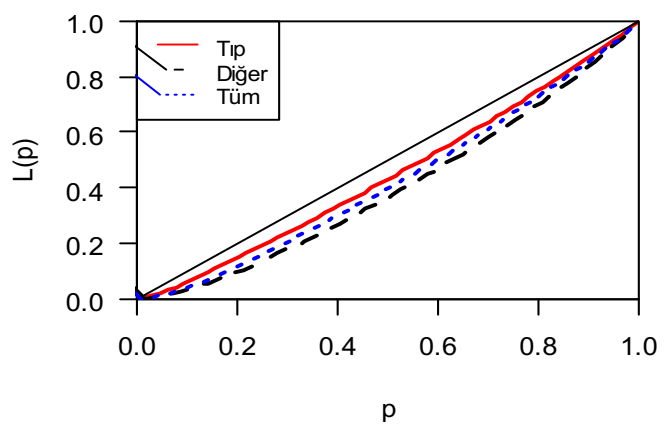

Şekil 2. 2010/2011 Dönemi ile 2018/2019 Döneminde Tıp Fakültesi olan (Tıp), Tıp Fakültesi Olmayan (Diğer) Üniversiteler ve Tüm Üniversitelere (Tüm) ait Lorenz Ĕgrileri 
Şekil 2'den de görüldüğü gibi bünyesinde tıp fakültesi olan üniversiteler ve tıp fakültesi olmayan üniversiteler ayrı ayrı değerlendirildiklerinde, mutlak eşitlik doğrusuna göre konumları tüm üniversitelerden oldukça farklıdır. Bu nedenle tıp fakültesi barındıran üniversitelerle diğer üniversiteler arasındaki farkın anlamlılığı iki bağımsız örneklem için uygulanan Wilcoxon Sıra Toplamı testi ile araştırılmıştır. Bu teste göre sıralanmış iki bağımsız örneklemin sıra toplamları (W) birbirine yakın ise, bu örneklemlerin geldiği iki anakütle birbirine benzemektedir. Aksine örneklemlerin sıra toplamları arasındaki fark büyükse, anakütleler birbirinden farklıdır. Wilcoxon Sıra Toplamı testinin sonuçları Tablo 4'de verilmiştir.

Tablo 4. Tıp Fakültesi Barındıran Üniversiteler ve Diğerleri Arasındaki Farkın Ölçümü için Wilcoxon Sıra Toplamı Testi

\begin{tabular}{|c|c|c|c|c|c|c|c|c|c|}
\hline Göstergeler & $\begin{array}{l}2010 / \\
2011\end{array}$ & $\begin{array}{l}2011 / \\
2012\end{array}$ & $\begin{array}{l}2012 / \\
2013\end{array}$ & $\begin{array}{l}2013 / \\
2014\end{array}$ & $\begin{array}{l}2014 / \\
2015\end{array}$ & $\begin{array}{l}2015 / \\
2016\end{array}$ & $\begin{array}{l}2016 / \\
2017\end{array}$ & $\begin{array}{l}2017 / \\
2018\end{array}$ & $\begin{array}{l}2018 / \\
2019\end{array}$ \\
\hline Makale* & 2453.5 & 2497 & 2692.5 & 2710.5 & 2650.5 & 2732.5 & 2912.5 & 2742.5 & 2759 \\
\hline Atıf & 2807.5 & 2785 & 2829 & 2784 & 2696.5 & 2550.5 & 2599 & 2475 & 2548 \\
\hline Doküman ${ }^{*}$ & 2626.5 & 2739.5 & 2897.5 & 2847.5 & 2829.5 & 2827.5 & 2913.5 & 2870.5 & 2950 \\
\hline Doktora & 2551 & 2597 & 2601 & 2489 & 2505 & 2545.5 & 2651 & 2647.5 & 2683 \\
\hline Ö̆g.ci/Öğ. Üye & 2518.5 & 2444.5 & $1801^{\ddagger}$ & $1911^{*}$ & $1911^{\ddagger}$ & 2246 & 2255 & 2389.5 & 2384 \\
\hline Toplam Puan & 2723 & 2852 & 2881 & 2825 & 2805 & 2786 & 2869 & 2859 & 2886 \\
\hline
\end{tabular}

Wilcoxon sıra toplamı testine göre öğrenci sayısı/ öğretim üyesi sayısı göstergesini 2012/2013, 2013/2014 ve 2014/2015 dönemleri arasındaki fark anlamsızdır. Ancak bu noktada URAP merkezi tarafından açıklanan 2013/2014 ve 2014/2015 dönemlerine ait öğrenci/ öğretim üyesi sayısı verilerinin tamamen aynı olduğu vurgulanmalıdır. Bu göstergenin ilgili dönemleri haricindeki tüm göstergeler için $\mathrm{H}_{0}$ reddedilerek, tıp fakültesine sahip okullarla tıp fakültesi olmayan okulların araştırma çıtıları arasında istatistiki olarak anlamlı fark olduğu sonucuna varılmıştır.

\section{Sonuç, Öneriler ve Kısıtlar}

Üniversiteler bilginin üretilmesi, bilginin yayılması, bilime, ekonomik ve teknolojik gelişime katkıda bulunmak yanı sıra toplumun aydınlanmasında rol oynamak gibi görevleri üstlenirler. Üniversiteler her yıl çeşitli sistemlere göre sıralanırlar. Üniversite sıralama sistemleri, çeşitli açılardan eleştirilse de, üniversitelerin kendi eksiklikleri görmeleri ve bu eksikleri düzeltip, geliştirmeleri için bir araç olarak önemlidir. Bu sıralamalar politika yapıcıların, ülkenin ürettiği akademik çıktı düzeyini ölçebilmeleri ve yükseköğretim sistemini iyileştirecek kararları almaları için de gösterge niteliğindedir. 
Türkiye'deki tüm üniversiteleri çeşitli araştırma çıktılarına göre sıralayan ilk ve tek ölçüt URAP'tır. Türkiye'de üniversitelerin sıralamasının değerlendirilmesine ilişkin literatürde çeşitli çalışmalar olmakla beraber, üniversitelerin ürettikleri araştırma çıktıları arasındaki farkın, dünya literatüründe sık kullanılan Gini katsayısı ile değerlendirildiği bir çalışmaya rastlanmamıştır.

$\mathrm{Bu}$ çalışmada, 121 devlet ve vakıf üniversitesinin araştırma çıktıları arasındaki fark Gini katsayısı ile ölçülmüştür. Bu ölçümde 2010-2018 yılları arasındaki URAP-TR sıralama göstergeleri esas alınmıştır. Çalışmada öncelikle 121 üniversitenin tamamı için Gini Katsayısı hesaplanmıştır. Ancak tıp fakültelerinin kaynak tahsisinin ve doktora öğrencisi sayısının diğer fakültelerden daha farklı olduğu bilindiği için Gini katsayısı, bünyesinde tıp fakültesi olan üniversiteler ve bünyesinde tıp fakültesi olmayan üniversiteler için de ayrı ayrı hesaplanarak, belli yıllar için bootstrap güven aralıkları bulunmuştur. Ayrıca Gini katsayıları ile elde edilen bulgular Lorenz eğrileriyle görsel açıdan da desteklenmiştir.

Elde edilen bulgulara göre, araştırma göstergelerinin diğer yıllardan daha farklı bir yöntemle hesaplandığ tek dönem olan 2010/2011 döneminde özellikle atıf sayısı ve doktora öğrencisi göstergeleri açısından üniversiteler arasındaki fark; hem genel, hem de tıp fakültesi içeren ve içermeyen üniversiteler şeklindeki sınıflamalar bakımından, en yüksek eşitsizliklerin mevcut olduğu dönemdir. Daha sonraki dönemlerde üniversiteler arasındaki eşitsizliğin makale sayısı, atıf sayısı, toplam doküman sayısı ve öğretim üyesi başına düşen öğrenci sayısı açısından, zamanla azaldığı ve tıp fakültesi içeren üniversiteler arasındaki eşitsizliğin, tıp fakültesi içermeyen üniversiteler arasındaki eşitsizliğe göre çok daha az olduğu görülmektedir. Tıp fakültesi içeren üniversiteler grubunda doğal olarak görece yüksek olan doktora öğrencisi sayısı üniversiteler arasında en yüksek eşitsizliğe yol açan gösterge olarak göze çarpmaktadır.

Uygulamanın son aşamasında ise söz konusu göstergeler açısından tıp fakültesi içeren ve içermeyen üniversite grupları arasındaki farkların istatistiksel olarak anlamlılı̆̆ 1 Wilcoxon Sıra Toplamları testi ile değerlendirilmiş ve her iki grup arasında araştırma çıktıları açısından anlamlı farklılık olduğu görülmüştür. Tıp fakültesi içeren üniversitelerin söz konusu araştırma çıtıları açısından kendi içlerinde daha benzer olduğu, eşitsizliğin daha az olduğu görülmüştür. Lorenz Eğrisi ve Gini Katsayısı beraber değerlendirildiğinde, üniversiteler arasındaki farkların zamanla kapandığı, hatta bünyesinde tıp fakültesi barındıran ve barındırmayan üniversiteler kendi içlerinde neredeyse eşit görünmektedir. Bu noktada dünya sıralamasında önceki yıllarda ilk 500'e giren üniversitelerin dahi, son iki dönemde ancak ilk 1000 üniversite arasına girdiği de unutulmamalıdır. Özellikle inceleme döneminin tümünde ortalama makale ve atıf sayılarının hemen hemen aynı kaldığı, bilimsel makalelere alınan atıfların dünya ortalamasının altında kaldığı ve yayınların çoğunlukla etki değeri en düşük olan dergilerde yapıldığı görülmektedir. Etki faktörü düşük dergilerde yayın yapılması, Türkiye'nin dünya sıralamasındaki yerinin düşük olmasının en önemli nedenidir (2018/2019 URAP Türkiye Sıralaması Basın Bildirisi, 2018, s.4). 
YÖK 2017 yılından itibaren araştırma üniversiteleri oluşturarak Türk üniversitelerinin akademik çıtı verimliliğini artırmayı ve dünya sıralamasındaki yerini yükselmeyi hedeflemiştir. Dünya sıralamasında Türk üniversitelerinin daha üst sıralamalara yerleşmesi için yoğun çaba harcansa da, Türkiye'de araştırma geliştirme faaliyetlerine ayrılan payın, gayri safi yurt içi hâsıla içinde 2010 yılında \% 0,8 düzeyinde olduğu ve 2016 yılında 0,94, yükselmiş olduğu da unutulmamalıdır. Dünya Bankası verilerine göre bu oran, 2016 yılında OECD ülkelerinde \% 2,49, Avrupa Birliğinde \% 2.03 ve ABD’de \% 2.74 düzeyindedir. Türkiye'de 2017 yllında da ancak \% 0,96 düzeyine ulaşan tüm araştırma geliştirme faaliyetleri içinde yükseköğretimin aldığ pay ise sadece $\% 33,5$ düzeyindedir.

YÖK tarafından ayrıca bilimsel faaliyetleri teşvik amacıyla 14/12/2015 tarihinde akademik teşvik yönetmeliği yürürlüğe konmuştur. Uygulanan teşvik programı ile kıyaslandığında, en yüksek teşvikleri alan üniversitelerin sıralamalarının URAP tarafından yapılan sıralama ile oldukça farklı olduğu görülmektedir. İki sıralamanın birbirinden bu kadar farklı olması, akademik teşvik almak amacıyla yapılan çalışmaların kalitesi hakkında düşülmesi gerektiğini ortaya koymaktadır. Bu noktada gelecek çalışmalarda iki sıralama arasındaki farkın da istatistiksel yöntemlerle incelenmesi düşünülmektedir.

\section{Kaynakça}

Abramo, G., Angelo, C.A., Di Costa, F. \& Solazzi, M. (2009). University Industry Collaboration in Italy: A Bibliometric Examination. Technovation, 29(6-7), 498-507.

Adam, D. (2002). Citation Analysis: The Counting House. Nature, 415, 726-729.

Al, U., Şahiner, M. \& Tonta, Y. (2006). Arts and Humanities Literature: Bibliometric Characteristics of Contributions by Turkish Authors. Journal of the American Society for Information Science \&Technology, 57(8), 1011-1022.

Alaşehir, O., Çakır, M. P., Acartürk, C., Baykal, N., \& Akbulut, U. (2014). URAP-TR: A National Ranking For Turkish Universities Based on Academic Performance. Scientometrics, 101, 159-178.

Avkuran, N., K. (2001). Investigating Technical and Scale Efficiencies of Australian Universities Through Data Envelopment Analysis. Socio-Economic Planning Sciences, 35, 57-80.

Beira E. (2010). Eugene Garfield, from ISI to Thomson Reuters: a timeline. Mercados E Negócıos: Dınâmıcas E Estratégıas Working Paper 104,1-17 
Bolay, S.H. (2011). Çağdaş Üniversitede Neler Önem Kazanmaktadır? Yükseköğretim ve Bilim Dergisi, 3, 105-112.

Bornmann, L, Mutz, R., Neuhaus, C. \& Daniel, D. (2008). Citation Counts For Research Evaluation: Standards of Good Practice For Analyzing Bibliometric Data and Presenting and Interpreting Results. Ethics in Science and Environmental Politics, 8, 93-102.

Cattell, J. M. (1906b). A Statistical Study of American Men of Science III. Science, 24(623), 732-742.

Çakır, M. P., Acartürk, C., Alaşehir, O., \& Çilingir, C. (2015). A Comparative Analysis of Global and National University Ranking Systems. Scientometrics, 103, 813-848.

Davidson, R. (2009). Reliable Inference for the Gini Index. Journal of Econometrics, 150(1), 3040.

Ellis, H. (1904). A Study of British Genius. London: Hurst and Blackett.

Erdem, A. R. (2013). Bilgi Toplumunda Üniversitenin Değișen Rolleri ve Görevleri. Yükseköğretim Dergisi, 3(2), 109-120.

Erdoğmuş, N. \& Esen M. (2016). Classifying Universities in Turkey by Hierarchical Cluster Analysis. Education and Science, 41, 363-382.

Erkoç, T. E. (2016). Measuring efficiencies of Turkish Public Universities with NonParametric Efficiency Estimation Method. Hacettepe Üniversitesi Eğitim Fakültesi Dergisi, 29(3), 124-136.

Erkut, E. (2015). Türkiye'deki Üniversitelerin Araştırma Çıktıları Üzerine. [Çevrim-içi: http://erhanerkut.com/wp-content/ uploads/2016/02/h-endeks.pdf], Erişim tarihi: 07.08.2018.

Galton, F. (1875). English Men of Science: Their Nature and Nurture. New York City: D. Appleton.

Garcia, N. R. \& Medina C. C. (2014). What Do University Rankings By Fieldsrank? Exploring Discrepancies Between the Organizational Structure of Universities and Bibliometric Classifications. Scientometrics, 98(3), 1955-1970.

Giles, D.E. (2004). Calculating A Standard Error For The Gini Coefficient: Some Further Results. Oxford B. Econ. Stat., 66(3), 425-433. 
Halffman, W. \& Leydesdorff, L., (2010). Is Inequality Among Universities Increasing? Gini Coefficients and the Elusive Rise of Elite Universitiesi. Minerva, 48, 55-72.

Huanga, M., Changa, H. W. \& Chenb. D. (2012). The Trend of Concentration in Scientific Research and Technological Innovation: A Reduction of the Predominant Role of the U.S. in World Research \& Technology. Journal of Informetrics, 6, 457-468

Jeon, J. \& Kim, S.Y., (2018). Is the Gap Widening Among Universities? On Research Output Inequality and Its Measurement in the Korean Higher Education System. Quality \& Quantity, 52, 589-606.

Lukman, R., Krajnc, D. \& Glavic, P. (2010). University Ranking Using Research, Educational and Environmental Indicators. Journal of Cleaner Production, 18, 619 - 628.

Maclean, A. H. H. (1900). Where we get our best men: Some statistics showing their nationalities, counties, towns, schools, universities, and other antecedents, 1837-1897. Marshall, Hamilton: Simpking.

Marginson, S. (2007). Global University Rankings: Implications in General and For Australia. Journal of Higher Education Policy and Management, 29(2), 131-42.

Ogwang, T. (2000). A Convenient Method of Computing the Gini Index and Its Standard Error. Oxford B. Econ. Stat, 62(1), 123-129.

Özbaşı, D. \& Uslu, B. (2018). Türk Üniversiteleri Sıralama Göstergelerinin Ağırlıklandırılması: University Ranking by Academic Performance (URAP) Türkiye Genel Sıralaması Örneği. Üniversite Araştırmaları Dergisi, 1, 62-70.

Rauhvargers A (2013) Global university rankings and their impact:Report II. Eur Univ Assoc, Brussels, [Çevrimiçi:https://eua.eu/downloads/publications/global\%20university\%20ran kings\%20and \%20their\%20impact\%20-\%20report \%20ii.pdf ], Erişim tarihi: 11.10.2018.

Selvitopu, A. \& Aydın, A. (2018). Türk Yükseköğretimince Uluslararasılaşma Stratejileri: Süreç Yaklaşımı Çerçevesinde Nitel Bir İnceleme. Hacettepe Üniversitesi Eğitim Fakültesi Dergisi, 33(4), 803-823.

Tomul, E. (2009). İlköğretim Okullarındaki Sosyal Adalet Uygulamalarına İlişkin Yönetici Görüşleri. Eğitim ve Bilim, 34(152), 126-137.

Usher, A. \& Savino, M. (2007). A Global Survey of University Ranking and League Tables. Higher Education in Europe, 32(1), 5-15. 
Van Raan, A. (2004). Measuring science. Handbook of Quantitative Science and Technology Research. USA: Dordrecht - Springer, 19-50.

Van Raan, A. (2005). Fatal Attraction: Conceptual and Methodological Problems in the Ranking of Universities by Biblometric Methods. Scientometrics, 62,133-143.

Ville, S., Valadkhani, A.\& O'Brien, M. (2006). The Distribution of Research Performance Across Australian Universities, 1992-2003, and Its Implications for Building Diversity. Australian Economic Papers, 45(4), 343-361.

Weingart, P. (2003). Evaluation of research performance: the danger of numbers. In: Bibliometric Analysis in Science and Research. Applications, Benefits and Limitations", Second Conference of the Central Library, Forschungszentrum Jülich, 7-19.

Weingart, P. (2005). Impact of Bibliometrics Upon the Science System: Inadvertent Consequences?, Scientometrics, 62(1), 117-131.

TÜBİTAK (2017). Girişimci ve Yenilikçi Üniversite Endeksi[Çevrim-içi: https://www.tubitak.gov.tr/sites/default/files/1095/ 2017_gyue_siralama.pdf], Erişim tarihi: 07.06.2018.

UNESCO-CEPES (2006). Berlin Principles on Ranking of Higher Education Institutions. [Çevrim-içi: https://www.che.de/downloads/Berlin_Principles_IREG_534.pdf], Erişim tarihi: 15.7.2018).

URAP (2017). URAP hakkında.[Çevrim-içi: http://tr.urapcenter.org/2017/hakkimizda.php], Erişim tarihi: 07.06.2018.

URAP (2018a). Dünya Bilim Alanı ve Genel Sıralamalarında Türk Üniversiteleri.[Çevrim-içi: http://tr.urapcenter.org/2017/DUNYA_BILIM_ALANI_ve_GENEL_SIRALAMALARI NDA_TURK_UNIVERSITELERI_22_07_2018.pdf], Erişim tarihi: 07.06.2018.

URAP (2018b). URAP ranking methodology. [Çevrim-içi: http://www.urapcenter.org/2018/ methodology.php?q=1], Erişim tarihi: 22.09.2018.

URAP (2019). 2018-2019 yılı dünya üniversiteleri sıralaması.[Çevrim-içi: http://www.urapcenter.org /2018/ country.php?ccode= TR\&rank=all], Erişim tarihi: 11.10.2018.

YÖK (2018). Yükseköğretim politikalarında Yeni YÖK. [Çevrim-içi: https://www.yok.gov.tr/Documents/ Yayinlar/Yayinlarimiz/ Yuksekogretim_politikalarinda_yeni_yok.pdf], Erişim tarihi: 11.10.2018. 